\title{
Factors Affecting the Level of Disclosure of Islamic Social Reporting (ISR) at Sharia Commercial Banks in Indonesia
}

\author{
Rimi Gusliana Mais * , Fajriana Ramadhanty \\ Department of Accounting, Sekolah Tinggi Ilmu Ekonomi Indonesia, Jakarta \\ *corresponding author e-mail: rimigusliana@gmail.com
}

\begin{abstract}
Article Info
Keywords:

Company Size;

Profitability;

Company Age;

Islamic Social Reporting (ISR)

Abstract

This is the study conducted to determine the factors influence the Islamic Social Reporting (ISR) level disclosure at the bank of Islamic Commercial in Indonesia in period of 2016-2020 where the variables are company size (SIZE), profitability (ROA), and company age (AGE). The quantitative method used in this study is a causal research strategy (cause and effect) with panel data regression based on the help of Eviews' 10. All Islamic Commercial Banks who registered in Financial Services Authority (OJK) in $2016-2020$ is population of this study. The researcher used the method of purposive sampling to choose the sample. The secondary data of this research gained from the reports of financial banking which is downloaded from its website. The researcher analyzed data by using multiple regression test and hypothesis testing. The results of this study indicate that there is a significant positive effect between company size, age and profitability on the level of disclosure in Islamic Social Reporting.
\end{abstract}

\section{Introduction}

Islamic banking, which is growing together with the country's economy, will be in the spotlight by the public. Sharia-based corporate social responsibility or Islamic Social Responsibility (ISR) is one that develops because it is directly related to the corporate environment and the wider community (Aini et al., 2017).

ISR is a development of Corporate Social Responsibility (CSR) which the government has required for all business sectors with limited liability companies. This case is exactly proven by the existence of Law No. 40 of 2007 concerning Limited Liability Companies (UPPT), which requires all companies to carry out social responsibility towards the surrounding environment and submit it in the form of an annual report (Mais and Lufian, 2018).

However, the government has not issued official laws or standard guidelines on reporting social responsibility for sharia-based companies. The final results of each company's report will be different because they are still voluntary or not mandatory.

Currently, Islamic banking in Indonesia is experiencing very rapid growth in demand, which has shown from the number of branch offices and sub-branches that have been established in various regions of Indonesia. Statistical data on Islamic banking in Indonesia in 2020 issued by the Financial Services Authority (OJK) until November 2020, there are 14 Islamic commercial banks with the total bank offices around 2.042 units in Indonesia. 
According to Fitria and Hartanti (2010), Islamic banking in Indonesia still uses CSR measurements that refer to the Global Reporting Initiative Index (GRI). The indicators contained in the GRI index are organizational profile and strategy, scope, and social scope. However, this assessment is considered inaccurate because the needles in the GRI index do not yet describe the sharia principles.

Haniffa (2002) had limitations in the conventional social reporting framework, so he put forward a conceptual framework, namely Islamic Social Reporting (ISR), which was then carried out based on sharia provisions that helped Muslims make decisions and assist companies in fulfilling their obligations to God and public.

Reporting Islamic social responsibility is developed by using the Islamic Social Reporting Index. As a benchmark of ISR index, the social performance of its implementation that contains a collection of standard CSR items that has established by the Accounting and Auditing Organization for Islamic Financial Institution (AAOIFI) and it will be developed by the researchers by regarding CSR items that should be revealed (Othman \& Thani, 2010).

It is essential to conduct further research related to ISR disclosure in Indonesia so that Islamic entities use the appropriate index to carry out social disclosures. It is hoped that in the future, the disclosure of ISR in Indonesia can be established by its regulations such as the Law that have been carried out by CSR so that sharia social disclosure in Indonesia becomes mandatory. Every form of sharia social disclosure by every sharia entity becomes the same.

In addition, with the disclosure of social responsibility activities, namely the revelation of ISR, this can be a good step between the company's relationship with the community, which is a form of ethics in Islam. Agustina (2013) revealed that the social impact occurred because of each company is not always be the same each other because there are many factors that distinguish each company even though the company is in the same type of business. The factors that determine companies are called company characteristics.

The disclosure of ISR is influenced by the factor of the size of a company. The size of a company has definition as the identification level about the size of it. Large companies have lots of planning and give more impacts to the stakeholders. They also have more public demand than the smaller one (Ramadhani, 2016).

Research conducted by Rizfani and Lubis (2018) and Sunarsih and Ferdiansyah (2016) said that company size has a positive and significant effect on ISR disclosure. It happens because the bigger the company, the higher the level of ISR disclosure in the annual report. In this case, large companies will undoubtedly get more attention from the community. Therefore, the company must try to build a good image in the eyes of society. Meanwhile, Prasetyoningrum (2019) stated that the size of company has no impact on ISR disclosure in Islamic banking.

Profitability is usually used in assessing the ability of company particularly in gaining profit. The higher the profitability, the more the company generates profits and discloses more comprehensive information in its annual report. Profitability is the potential profit obtained by the bank from its business activities (Mokoginta, Karamoy, \& Lambey, 2018)

Increasing the number of profitability values gives the company a high opportunity to grow. The higher the company's profit, making it able to bear the higher costs of compiling the disclosure of social reports. According to research conducted by Kartini (2016) and Widiarto (2017) explaining ISR disclosure effected to the profitability, in contrast, to study born Prasetyoningrum (2019) and Sari (2019) which explains that profitability has no impact on ISR disclosure.

The age of a company will indicate the time the company was founded, or in short it means roughly how long the company was formed and operated. Consequently, the longer the company can survive, the more widely the company discloses its social information as a form of responsibility 
compared to a newly established company. Research conducted by Yuvita Sari (2018) and Aini et al. (2017) states that the age of a company giving an effect on ISR disclosure, but on the contrary, it is obtained from research by Rosadi (2021) which said that company age does not give impact on ISR disclosure.

Based on the description of the background above, which explains that there are still differences in the results between the studies and considering the significant potential of Islamic banks in Indonesia. Researchers will examine the extent to which Islamic banking, especially the bank which are listed as the registration in the Financial Services Authority (OJK), demonstrate their social responsibility in disclosing matters relating to Islamic principles.

\section{Literature Review}

\section{Islamic Social Reporting}

Othman and Thani (2010) state that Islamic Social Reporting (ISR) is a standard for reporting the social performance of sharia-based companies. According to Ramadhani (2016), ISR is a standard for reporting corporate social performance that uses sharia principles. The purpose of ISR is as a form of corporate accountability to Allah SWT and society, to increase the transparency of business activities by presenting relevant information by taking into account the spiritual needs of Muslim investors or sharia compliance in decision making.

According to Deviani (2018), the ISR index is disclosure items used as indicators in reporting the social performance of business institutions with sharia principles. She made five themes for disclosing the ISR Index, namely the Funding and Investment Theme, Product and Service Theme, Employee Theme, Community Theme, and Environmental Theme. Then it was developed by Othman et al. (2009) by adding one disclosure theme, namely the Corporate Governance Theme. Each disclosure theme has a sub-theme as an indicator of the disclosure of the theme. The following are six disclosure themes in the ISR index:

a. Financing and Investment

Disclosures on this theme are operational activities containing usury, gharar, zakat management, transactions forbidden by Islam, and items regarding company policies or sharia commercial banks in dealing with problematic customers. According to Firdaus (2017), gharar lacks clarity or doubt about the existence of a commodity that is the object of the contract; it is unclear how to get between profit and loss. Technically maysir means speculation.

b. Products and services

This theme needs to be disclosed in the halal status of the products used and services for consumer complaints whose purpose is so that stakeholders know that the goods or services are allowed or prohibited in Islamic teachings.

c. Employees

This theme underlies the ethical themes of trust and justice, so employees must be treated fairly and paid fairly and meet their spiritual needs. Haniffa (2002) and Othman and Thani (2010) explained that the Islamic community wants to know whether the company's employees have been treated fairly and fairly through the information disclosed, such as wages, job characteristics, working hours per day, annual holidays, guarantees. Health and welfare, policies related to time and place of worship, education and training, equal rights, and the work environment. 


\section{d. Community}

This theme is about ummah, amanah, and adl which emphasizes the importance of sharing and lightening the burden on the community which can be done with alms, waqf, and qard. All forms of assistance and contributions that the company provides to the community must also be disclosed.

e. Environment

This theme emphasizes balance, simplicity, and responsibility in protecting the environment. Therefore, information related to the use of resources and programs used to protect the environment must be disclosed in the company's annual report (Othman \& Thani, 2010). It is expected that Islamic banks will preserve the environment by contributing or supporting CSR activities. Therefore, Islamic banks must report every nature and amount of each contribution made to protect the environment and must disclose whether Islamic banks have financed projects that can cause environmental losses and damage.

\section{f. Corporate Governance}

Corporate governance is a set of regulations that establish the relationship between shareholders, management, creditors, government, employees, and other internal and external stakeholders concerning their rights and obligations, or in other words, the system that directs and controls the company.

Information disclosed in the corporate governance theme is the status of compliance with sharia, details of names and profiles of directors, DPS and commissioners, performance reports of commissioners, DPS and directors, remuneration policies for commissioners, DPS and directors, reports on income and use of non-halal funds, case reports law, share ownership structure, anticorruption, and anti-terrorism policies.

\section{Company Size}

The larger the company's size, the more information available to investors in making decisions related to investing in the company. Company size describes the size of a company as measured by total assets. Large companies tend to have a higher public demand for information than smaller companies (Khairiah \& Fuadi, 2017). Ramadhani (2016) states that company size is the level of identification of the size of a company. Large companies usually carry out more activities and have a significant impact on stakeholders. Larger companies tend to have a higher public demand for information than smaller companies.

\section{Profitability}

According to Sartono (2010), profitability is the company's ability to earn profits about sales, total assets, and own capital. The profitability ratio is a ratio to assess the company's ability to seek profit or profit. This ratio also provides a measure of the effectiveness of a company's management (Kasmir 2014). According to (Hery 2016) the profitability ratio is used to measure the company's ability to generate profits from its business activities. In addition to aiming to determine the company's ability to generate earnings during a specific period, the profitability ratio also seeks to measure the effectiveness of management in running the company's operations. A profitability ratio is a ratio that describes the company's ability to generate profits through the capabilities and resources owned, namely those derived from the sales force, use of assets, and use of capital.

\section{Company Age}

Wati (2019) states that the company's age is the length of life calculated from the first time the company was established until now carrying out its activities in business to make a profit or profit. The longer a company operates or, the older the company's ages, the company is likely to provide more and broader information than a newly established company. 


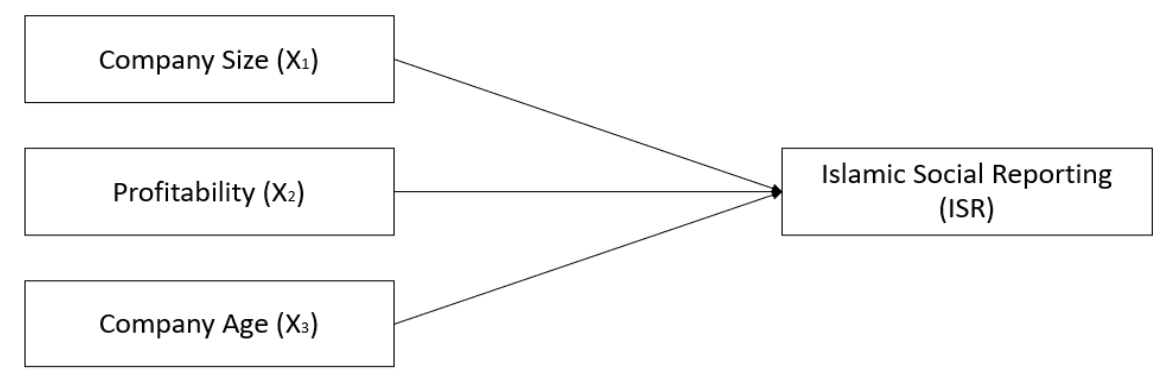

Figure 1. Frame of Mind

\section{Research Method}

\section{Population and Research Sample}

This study uses quantitative methods because the analysis uses statistical calculations using multiple regression test tools. This study has purpose to find a relationship between one variable and another, where there are independent variables, such as size of company, profitability, the age of company, and a variable dependently, namely the uncovering of ISR at Islamic Commercial Banks registered in Financial Services Authority (OJK) period 2016-2020.

The population, according to Sugiyono (2017), "The area of generalization has objects and subjects with the determination of qualities and characteristics to be studied and making conclusion." Islamic Commercial Banks (BUS) is the population in this study which registered by the OJK period 2016-2020, and it consists of 14 BUS.

Sampling from the population was carried out by purposive sampling, namely determining samples with certain considerations that were deemed to be able to provide maximum data. They are:

a. Sharia Commercial Banks (BUS) has registration to OJK for five periods, in 2016-2020.

b. Sharia Commercial Banks use Rupiah in presenting all of their company reports.

c. Sharia Commercial Banks publish annual reports on their respective official websites for 20162020.

\section{Sources and Types of Research Data}

The secondary data that was collected as the type of data for this research has been gained from lastly report in the five consecutive years that is from 2016 to 2020. The type of data is collected from secondary data derived from annual reports for five consecutive years, 2016-2020, from each Islamic Commercial Bank registered at the OJK. The data gained from the Islamic banking official website.

The data collection method used to collect and obtain research data used in this study is documentation data. According to Sugiyono (2017), Documentation is a record of events that have passed in the form of pictures, photos, sketches, and others.

\section{The Operation of Variables}

Sugiyono (2017) suggests that the variable is everything that must be determined by the researcher so that the information about the study will be easier to know and to decide the conclusion. Here are the variables of this research such as a variable that dependently and three variable that independently. The independent variables in this study include company environmental performance, company age, company size, and profitability.

a. Company Size $\left(\mathrm{X}_{1}\right)$

The company size can be calculated in the same time with the total assets of company, where it shows that the amount of its assets of the company and it divided into current assets and fixed assets. The total assets in the annual report can present whether a company is included in large or small 
companies. Therefore, the author uses a proxy of total assets to measure company size. The variable size of this company uses the rupiah currency and is given the symbol "size". To equate the total variable assets processed with other data variables, use the company size in the natural logarithm (Ln) to form the formula:

$\mathrm{SIZE}=\operatorname{Ln}($ Total Asset $)$

b. Profitability $\left(\mathrm{X}_{2}\right)$

A company should have ability to make profit from its company that also called as profitability and it can be calculated by using Return on Assets (ROA), the ratio of ROA can be measuring the ability of a company in generating net income by followed a certain level of assets. ROA helps to show the ratio that is about the total number of company's assets used for, because it describes its operational performance in generating profits (Hanafi \& Halim, 2016). ROA value divides Net Income by Total Assets:

$\mathrm{ROA}=($ Net Income $/$ Total Assets $)$

c. Company Age $\left(\mathrm{X}_{3}\right)$

Company age is used to the measurement of the effect of the company's length. The calculation of company age can be started from the first time of company's establishment or operation until the company maintains its existence in the business world by measuring:

Age $=$ The year the company was researched - The year the company started operating

d. Islamic Social Reporting Index (Y)

The content analysis method helps to measure ISR index in aims to identify the type of its disclosure in two ways, reading and analyzing the annual report of company. Content analysis is a method of analyzing data through observation and analysis techniques on the content and messages. The content analysis step is by scoring based on the ISR index, which consists of 6 indicators. Each disclosure item has a score of 1 or 0 . A score of 1 will be given if the ISR item is contained in the company data, and a score of 0 will be given if the ISR item is not found in the company data.

The way to do a comparative assessment between Islamic Social Reporting Disclosure (ISRD) is to compare the disclosures of ISR carried out by the company, and the maximum number of exposures of ISRD by the company. The ISRD formula is:

ISR $=$ Number of score disclosures filled / Maximum Score Disclosure Score

\section{The Description of Data Analysis}

An overview of the research variables, namely Islamic Social Reporting disclosure, company size, profitability, and company age, in a descriptive statistical table shows the minimum, maximum, mean, and standard deviation figures.

\section{Panel Data Regression Estimation Method}

According to (Widarjono, 2018), there are several methods that commonly used to estimate or to calculate the regression models with panel data, such as:

a. Common Effects models

It is the most straightforward model approach technique in calculating and explaining panel data by the combination of data as cross-section and the series of time. Merging this data is treated as a single observation with the Ordinary Least Square (OLS) approach. OLS is a method to calculate the population regression function. 


\section{b. Fixed Effect Model}

The technique used to estimate panel data is fixed effect model, where it uses the dummy variables in capturing differences in intercepts. Dummy variables provide different parameter values, both across cross-sectional units and times series units. This approach by including a dummy variable is commonly referred to as the Least Square Dummy Variable (LSDV).

c. Random Effect Model

To overcome fixed-effect model weakness, random effect model can be used for this, also can avoid the use of dummy variable technique that can cause uncertainty experiences of the model. The random effect approach improves the efficiency of a minor square process by considering the errors from the cross-section and times series.

\section{Results and Discussions}

\section{The Analysis of the Data}

In analyzing of the data, the researcher used in this study consisted of five types of analysis, namely descriptive analysis statistically, analysis on the panes data regression, the estimation model selection, data quality testing, and hypothesis testing using the Eviews 10.0 software.

\section{Descriptive Statistical Analysis}

The using of this analysis data is to see the data description. It is obtained from descriptive analysis and it shows the average of data (mean), the highest value or highest total number of data (maximum), the lowest value or lowest total number of data (minimum), and the standard deviation of each independent and dependent variable. Descriptive statistics of each variable studied area follow total pages. The column can be numbered if the title in each table column is long and complicated, and at the bottom of the table can be written by the description. Placing table at the top or bottom of each page in aims to not flanked by sentences and to avoid the interruption table by page.

Table 1. Descriptive Statistics Test

\begin{tabular}{lcccc}
\hline & ISR & SIZE & ROA & AGE \\
\hline Mean & 0.731200 & 30.49554 & 0.010828 & 11.50000 \\
Maximum & 0.860000 & 32.47448 & 0.090986 & 29.00000 \\
Minimum & 0.540000 & 29.23958 & -0.112275 & 2.000000 \\
Std. Dev. & 0.079710 & 0.994158 & 0.028655 & 6.503531 \\
\hline Observations & 50 & 50 & 50 & 50 \\
\hline
\end{tabular}

Source: Eviews Panel Data Regression Output Results Version 10.0

From the table 1, it is known that the number of observations of study was 50 . It can be seen that for the dependent variable the ISR reaction shows a minimum value 0.540000 , the maximum value of ISR is 0.860000 , the average ISR reaction is 0.731200 , and standard deviation of ISR is 0.079710 .

The natural logarithm of total assets measures size. By obtaining a minimum value of 29,239 with a tangible asset of Rp. 4,995,606,338,455, which the Bank Central Asia Syariah company received and a maximum value of 32,474 with a total asset of Rp. 126,907,940,000,000 in Bank Syariah Mandiri. The standard deviation is 0.994 and the average value is 30,495.

The following variable is Return on Assets (ROA). ROA shows a minimum value of -0.112 at the Panin Dubai Syariah Bank, while the maximum value is 0.090 at the Syariah National Pension Savings Bank; this means that the bank can generate a net profit of up to 0.090 of the total owned by the company. Therefore, it has an average value of 0.010 with a standard deviation of 0.028 . This 
illustrates that the average value of ROA is smaller than the deviation value; this shows the high variation between the maximum and minimum values during the observation period.

The last variable is company age. The company's age obtained a minimum value of 2,000 at the National Sharia Pension Savings Bank and a maximum value of 29,000 at Bank Muamalat Indonesia with an average value of 11,500 and a standard deviation of 6,503 . The value of deviation is smaller than the average value owned. This shows the low variation between the maximum and minimum age values during the observation period; in other words, there is no large enough gap between the lowest and highest ages.

\section{Classic assumption test}

The classical assumption test in this study is by the provisions and has met the criteria for passing the test. This test divided into two kinds of test, namely the multicollinearity test and heteroscedasticity test.

1. Multicollinearity Test

The multicollinearity test results that the regression model found a high or perfect correlation among all variables as independently. A good regression model should not have the correlation among all of the variables independently. Multicollinearity tests between variables can be identified using the correlation value between independent variables (Ghozali and Ratmono, 2013)

Table 2. Multicollinearity Test

\begin{tabular}{lcrr}
\hline & ROA & \multicolumn{1}{c}{ SIZE } & \multicolumn{1}{c}{ AGE } \\
\hline ROA & 1.000000 & -0.069257 & -0.306415 \\
SIZE & -0.069257 & 1.000000 & 0.661553 \\
AGE & -0.306415 & 0.661553 & 1.000000 \\
\hline
\end{tabular}

The results obtained from the multicollinearity test show that the correlation value between the independent variables (company size, profitability, and company age) is less than 0.80 , then $\mathrm{H}_{0}$ is accepted. It can be concluded that there is no multicollinearity problem between independent variables in the regression model.

2. Heteroscedasticity Test

Winarno (2015) state the methods used to identify the heteroscedasticity problems are glejser test, park test, goldfield quandt test, spearman correlation test, breuschh-pagan-godfres, and white test. The heteroscedasticity test used in this study is the Breusch-pagan-Godfrey test. According to Winarno (2015), "This Breusch-Pagan-Godfrey test is a to detect the presence of heteroscedasticity in a model which is a refinement of the Goldfeld-Quandt test. The G-Q test has an excellent ability to be applied to small samples, while the B-P-G test can be used well for large models."

Table 3. Heteroscedasticity Test

\begin{tabular}{lccc}
\hline \multicolumn{1}{c}{ Test } & Statistic & d.f. & Prob. \\
\hline Breusch-Pagan LM & 46.74179 & 45 & 0.4007 \\
Pesaran scaled LM & 0.183601 & & 0.8543 \\
Bias-corrected scaled LM & -1.066399 & & 0.2862 \\
Pesaran CD & -0.035970 & & 0.9713 \\
\hline
\end{tabular}

From the test statistics above, because the probability value is 0.4007 and 0.4007 is more than 0.05 , then $\mathrm{H}_{0}$ is not rejected, so it can be concluded that there is no heteroscedasticity in the model, with a significant level of 0.05 . Therefore, from the results obtained can be continued to the subsequent stage. 
3. Hypothesis testing.

Multiple regression analysis can inform about the more than one effect of independent variable on one dependent variable. The independent variable in this study is Company size, Profitability, and company age. At the same time, the dependent variable is Islamic Social Reporting (ISR).

Table 4. Panel Data Regression Analysis Results

\begin{tabular}{lcccc}
\hline Variable & Coefficient & Std. Error & t-Statistic & Prob. \\
\hline C & 1.209215 & 1.059140 & 4.141695 & 0.0144 \\
SIZE & 0.018479 & 0.036178 & 3.510782 & 0.0251 \\
ROA & 0.220452 & 0.318687 & 5.691750 & 0.0094 \\
AGE & 0.007229 & 0.005468 & 3.321993 & 0.0343 \\
\hline
\end{tabular}

From the table explained above, the equation of the regression of panel data with the model of fixed-effect is obtained as follows:

$$
\text { ISR }=1.209+0.018 \mathrm{SIZE}+0.220 \mathrm{ROA}+0.007 \mathrm{AGE}+\varepsilon
$$

The data listed has been equation above can be explained as below:

1. The constant value of 1,209 can be interpreted if there is none company size, profitability, and age, then the ISR variable will be worth 1,209.

2. Company size variable has a coefficient value of 0.018 . coefficient value positive regression illustrates that every one unit in size assuming other variables will increase ISR of 0.018 .

3 . The profitability variable has a coefficient value of 0.220 . This value indicates that the variable gives effect positively on ISR. If it is assumed that the value of the other independent variables is constant, when there is an increase in the variable, the ISR value will increase by 0.220 .

4. The variable of the age has a coefficient number valued of 0.007 . This value indicates that the variable gives effect positively on ISR. If it is assumed that the value of the other independent variables is constant, when there is an increase in the variable, the ISR value will increase by 0.007 .

a. Coefficient of Determination Test

The coefficient of determination (R2) essentially measures how far the model can explain variations in the dependent variable. The value of $\mathrm{R} 2$ is between zero and one. The small matter of R2 means that the ability of the independent variables to explain the variation of the dependent variable is limited. A value close to one means that the independent variables provide almost all the information needed to predict the interpretation of the dependent variable. In general, the value of R2 for cross-sectional data is relatively low because of the significant variation between each observation. Meanwhile, time-series data usually has a high R2 value (Ghozali \& Ratmono, 2013).

Tabel 5. Coefficient of Determination Test Results

\begin{tabular}{llll}
\hline R-squared & 0.823724 & Mean dependent var & 0.731200 \\
Adjusted R-squared & 0.766554 & SD dependent var & 0.079710
\end{tabular}

In the table above, the R-squared value of 0.823 or $82.3 \%$ of the independent variables can affect the ISR variable. In comparison, the remaining $17.7 \%$ is influenced by other variables not included in this research model. 
b. F test

The $\mathrm{F}$ test shows whether all the independent variables included in the model have a joint influence on the dependent variable (Ghozali \& Ratmono, 2013).

$\mathrm{H}_{0}$ : There is no effect of the independent variable on ISR

$\mathrm{H}_{1}$ : There is an effect of the independent variable on ISR

Table 6. F Test Results

\begin{tabular}{llll}
\hline R-squared & 0.823724 & Mean dependent var & 0.731200 \\
Adjusted R-squared & 0.766554 & S.D. dependent var & 0.079710 \\
S.E. of regression & 0.038513 & Akaike info criterion & -3.456760 \\
Sum squared resid & 0.054880 & Schwarz criterion & -2.959634 \\
Log likelihood & 99.41899 & Hannan-Quinn criter. & -3.267451 \\
F-statistic & 14.40820 & Durbin-Watson stat & 2.070325 \\
Prob(F-statistic) & 0.000000 & & \\
\hline
\end{tabular}

From the table of the F Test above, we know that the F-statistic value is 14,408 with a value as significantly of 0.000 and the level of that significance of $5 \%, 0.000<0.05$, so that rejecting $\mathrm{H}_{0}$ means that it can be concluded that simultaneously the independent variables have a significant effect on ISR.

c. T Test

Table 7. T Test Results

\begin{tabular}{lllll}
\hline Variable & Coefficient & Std. Error & t-Statistic & Prob. \\
\hline C & 1.209215 & 1.059140 & 4.141695 & 0.0144 \\
SIZE & 0.018479 & 0.036178 & 3.510782 & 0.0251 \\
ROA & 0.220452 & 0.318687 & 5.691750 & 0.0094 \\
AGE & 0.007229 & 0.005468 & 3.321993 & 0.0343 \\
\hline
\end{tabular}

From the testing data on the table above, we can make conclusion about the variables of Firm Size (SIZE), profitability (ROA), Company Age (AGE) are positive and significant to the dependent variable, namely Islamic Social Reporting. The following is an explanation of each variable:

1. The SIZE hypothesis on ISR

$\mathrm{H}_{0}$ : There is no significant effect of SIZE on ISR

$\mathrm{H}_{1}$ : There is a significant effect of SIZE on ISR

The t-statistic value is 3.510 , and the probability is 0.0251 . The significance level used is $5 \%$, then $0.0251<0.05$, so we reject $\mathrm{H}_{0}$. It can be concluded that there is a significant effect between the SIZE variable on the ISR variable.

2. The ROA Hypothesis on ISR

$\mathrm{H}_{0}$ : There is no significant effect of ROA on ISR

$\mathrm{H}_{1}$ : There is a significant effect of ROA on ISR

The $t$-statistic value is 5.691 , and the probability is 0.0094 . The significance level used is $5 \%$, so $0.0094<0.05$ so that we reject $\mathrm{H}_{0}$. It can be concluded that there is a significant effect between the ROA variable on the ISR variable.

3. The AGE hypothesis on ISR

$\mathrm{H}_{0}$ : There is no significant effect of AGE on ISR

$\mathrm{H}_{1}$ : There is a significant effect of AGE on ISR

Based on the t-test above, the t-statistic value is 3.321 , and the probability is 0.0343 . The significance level used is $5 \%$, so $0.0343<0.05$ so that we reject $\mathrm{H}_{0}$. It can be concluded that there is a significant effect between the AGE variable on the ISR variable. 


\section{The Effect of Company Size on Disclosure of Islamic Social Reporting}

From the result above, it shows that a profitability level of 0.0251 which means the company's size has a positive coefficient value. $5 \%$ as the significant level used, and the company's size also resulted same to disclosure of Islamic Social Reporting by $0.0251<0.05$.

This case shows about the larger size of a company, the greater of social responsibility. Large companies tend to disclose ISR more broadly so that more information is available. Companies with a larger size tend to have a higher demand for information by the public than smaller one because large companies are issuers that are widely highlighted by the public.

The results of this study are similar with the research by Aini et al. (2017) and Rizfani and Lubis (2018), which has stated that the size of a company has a positively and significantly effect on the disclosure of Islamic Social Reporting. This study is different from research Prasetyoningrum (2019) which says that size of a company has no significant effect on ISR disclosure.

\section{The Effect of Profitability on Disclosure of Islamic Social Reporting}

There is the result taken from listed data above, it explained about the profitability has a positive coefficient value with a probability level of 0.0094 . The significance level used is $5 \%$, so $0.0094<$ 0.05 , which means that profitability has a significant effect positively on the Islamic Social Reporting's disclosure.

This case absolutely proves that profitability is closely related to effectiveness of a company's management in managing the profits earned by the company. Companies with a higher level of profit will attract investors, so the company's efforts to provide better information to the public and potential investors are by increasing the disclosure of social responsibility. The higher the profitability means the higher the company's ability to generate profits so that the company's disclosures will be more comprehensive and the costs for disclosure of social responsibility will also be more realized. Therefore, the higher the profitability, the higher the ISR.

The results of this study are similar to the research by Aini et al. (2017) and Kartini (2016), that shows the significant effect of profitability, on the disclosure of Islamic Social Reporting. But, this is not similar with the research by Novrizal and Fitri (2016), which resulted about no significant effect of profitability on ISR disclosure.

\section{The Effect of Company Age on Disclosure of Islamic Social Reporting}

The results above indicate that the age of a company has a positive value coefficient with a probability level of 0.0343 . The significance level used is $5 \%$, so $0.0343<0.05$, which means that the company's age has a significant effect positively on the disclosure of Islamic Social Reporting.

As the previous explanation, it should be concluded the age of the company affects the disclosure of Islamic Social Reporting because a company with a long-standing will get more trust from investors (capital owners) and is also known to significantly affect the company's financial statements because it has more information related to the development and growth of the company. This is also based on the fact that having an older age will reveal more details in the annual report compared to new company because when the company has been around for a long time, they will should know about the company state including internally or externally. Will also get to know and understand the state of the external company environment. Accordingly companies tend to understand more about the needs and responsibilities of the company.

The results of this study are similar to the research by Aini et al. (2017) that shows the significant company's age on the disclosure of Islamic Social Reporting. . But, this is not similar with the research by Rizfani and Lubis( 2018), which resulted about no significant effect of company age on ISR disclosure. 


\section{Conclusions}

After explaining about the result of research and discussion, we can conclude several points as below:

1. The size of company has a significant positive effect on the level of Islamic Social Reporting (ISR) disclosure at Islamic Commercial Banks in Indonesia for the 2016-2020 period. In this study, we can see that the positive coefficient as the effect to the larger size of a company. This shows that the larger size of the company, the greater the disclosure of ISR so that more company information is provided to the public.

2. Profitability proxied by Return on Assets (ROA) gives the significant positive effect on the level of Islamic Social Reporting (ISR) disclosure at Islamic Commercial Banks for the 2016-2020 period. In this study, ROA has a positive coefficient. This shows that the higher the profitability, the higher the company's ability to generate profits. The company's disclosures will be more comprehensive, and the costs for social responsibility disclosure will also be realized. Hence the higher the profitability, the higher the ISR.

3. Company age or age has a positive effect significantly on the level of Islamic Social Reporting (ISR) disclosure at Islamic Commercial Banks in Indonesia for the 2016-2020 period. In this study, a positive coefficient has impacted to the company age. This shows that the greater the company's age or, the longer the company operates, the wider the ISR disclosure meant.

\section{References}

Agustina, Silvia. 2013. Pengaruh Profitabilitas dan Pengungkapan Corporatesocial Responsibility Terhadap Nilai Perusahaan: Studi Empiris Pada Perusahaan Manufaktur yang Terdaftar di Bursa Efek Indonesia. Jurnal Akuntansi, 1(1).

Aini, Nur; Susilowati, Yeye; Indarti, Kentris \& Age, Ratna Fauziyyah. 2017. Pengaruh Umur Perusahaan, Ukuran Perusahaan, Leverage, Likuiditas, Profitabilitas dan Kinerja Lingkungan Hidup Terhadap Pengungkapan Islamic Social Reporting Pada Perusahaan yang Terdaftar di Jakarta Islamic Index (JII) Tahun 2012 - 2015. Dinamika Akuntansi, Keuangan dan Perbankan, 6(1), 67-82.

Deviani, Ruri. 2018. Analisis Faktor-Faktor Yang Mempengaruhi Pengungkapan Islamic Social Reporting. Skripsi. Universitas Islam Indonesia.

Firdaus, Achmad. 2017. Maslahah Performa: Sistem Manajemen Kinerja Berbasis Maslahah. Yogyakarta: K-Media.

Fitria, Soraya \& Hartanti. 2010. Islam dan Tanggung Jawab Sosial: Studi Perbandingan Pengungkapan Berdasarkan Global Reporting Initiative Indeks dan Islamic Social Reporting Indeks. Simposium Nasional Akuntansi 13.

Ghozali, Imam \& Ratmono, Dwi. 2013. Analisis Multivariat dan Ekonometrika: Teori, Konsep dan Aplikasi dengan Eviews 8. Semarang: UNDIP.

Hanafi, Mamduh M. \& Halim, Abdul. 2016. Analisis Laporan Keuangan (cet. ke-5). Yogyakarta: UPP STIM YKPN.

Haniffa, R. 2002. Social Reporting Disclosure: An Islamic Perspective. Indonesian Management \& Accounting Research, 1(2), 128-146.

Hery. 2016. Analisis Laporan Keuangan. Jakarta: PT. Gramedia Widiasarana Indonesia.

Kartini. 2016. Faktor-Faktor yang Mempengaruhi Pengungkapan Islamic Social Reporting pada Perusahaan yang Masuk Jakarta Islamic Index Periode 2011-2014. Skripsi. Universitas Islam Negeri Hidayatullah.

Kasmir. 2014. Analisis Laporan Keuangan ( $7^{\text {th }}$ ed). Jakarta: PT Raja Grafindo Persada.

Khairiah \& Fuadi, Raida. 2017. Faktor-Faktor Yang Mempengaruhi Pengungkapan Sukarela

dalam Laporan Tahunan: Studi pada Perbankan Syariah di Indonesia. Jurnal Ilmiah Mahasiswa 
Ekonomi Akuntansi (JIMEKA), 2(1), 63-72.

Mais, Rimi Gusliana and Lufian, Nuning. 2018. Pengaruh Sharia Governance Structure Terhadap Pengungkapan CSR Berdasarkan Islamic Social Reporting Index. Jurnal Akuntansi dan Manajemen, 15(1), 83-100.

Mokoginta, Rena Mustari; Karamoy, Herman \& Lambey, Linda. 2018. Pengaruh Komisaris Independen, Dewan Pengawas Syariah, Kepemilikan Institusional, dan Profitabilitas Terhadap Tingkat Pengungkapan Tanggung-Jawab Sosial pada Bank Syariah di Indonesia. Jurnal Riset Akuntansi dan Auditing (Goodwill), 9(1), 55-71.

Novrizal, Muhammad Fajrul \& Fitri, Meutia. 2016. Faktor-Faktor yang Mempengaruhi Pengungkapan Corporate Social Responbility (CSR) pada Perusahaan Yang Terdaftar di Jakarta Islamic Index (JII) Tahun 2012- 2015 dengan Menggunakan Islamic Social Reporting (ISR) Index Sebagai Tolak Ukur. Jurnal Ilmiah Mahasiswa Ekonomi Akuntansi, 1(2),177-89.

Othman, Rohana \& Thani, Azlan Md. 2010. Islamic Social Reporting of Listed Companies in Malaysia. International Business \& Economics Research Journal (IBER), 9(4), 135-44.

Othman, Rohana; Thani, Azlan Md \& Ghani, Erlane K. 2009. Determinants of Islamic Social Reporting Among Top Shariah-Approved Companies in Bursa Malaysia. Research Journal of International Studies-Issue, 12(4).

Prasetyoningrum, Ari Kristin. 2019. Pengaruh Ukuran Perusahaan, Profitabilitas, Leverage, Efisiensi Biaya, dan Umur Perusahaan Terhadap Islamic Social Reporting (ISR) pada Perbankan Syariah di Indonesia. MALIA: Journal of Islamic Banking and Finance, 2(2), 147-162.

Ramadhani, Febry. 2016. Pengaruh Ukuran Perusahaan, Profitabilitas, Leverage dan Ukuran Dewan Pengawas Syariah Terhadap Pengungkapan Islamic Social Reporting. JOMFekom, 3(1), $2487-$ 2500 .

Rizfani, Khaerun Nissa \& Lubis, Deni. 2018. Pengungkapan Islamic Social Reporting pada Perusahaan di Jakarta Islamic Index Disclosure of Islamic Social Reporting among Companies in Jakarta Islamic Index. Jurnal Al-Muzara'ah, 6(2), 2615-7659.

Rosadi, Ahmad Bayu Wreda. 2021. Pengaruh Profitabilitas, Leverage, Ukuran Perusahaan, Likuiditas, Umur Perusahaan, dan Ukuran Dewan Komisaris Terhadap Islamic Social Reporting Pada Perusahaan yang Terdaftar di Jakarta Islamic Index. Skripsi. Institut Agama Islam Negeri Tulungagung.

Sari, Wulan. 2019. Pengaruh Islamic Social Reporting, Intellectual Capital dan Ukuran Perusahaan Terhadap Kinerja Keuangan Perbankan Syariah di Indonesia. Skripsi. Institut Informatika dan Bisnis Darmajaya.

Sartono, Agus. 2010. Manajemen Keuangan Teori dan Aplikasi (4th ed.). Yogyakarta: BPFE.

Sugiyono. 2017. Metode Penelitian Kuantitatif, Kualitatif, dan R\&D. Bandung: Alfabeta CV.

Sunarsih, Uun \& Ferdiansyah, Ferdiyansyah. 2016. Determinants of The Islamic Social Reporting Disclosure. Al-Iqtishad: Journal of Islamic Economics, 9(1), 69-80.

Wati, Ria. 2019. Pengaruh Ukuran Perusahaan, Profitabilitas dan Leverage Terhadap Pengungkapan Islamis Social Reporting (ISR) pada Perusahaan yang Terdaftar di Jakarta Islamic Index (JII). Artikel Ilmiah, 8(5), 1-15.

Widarjono, Agus. 2018. Ekonometrika Pengantar dan Aplikasinya Disertai Panduan Eviews (ed. Ke5). Yogyakarta: UPP STIM YKPN.

Widiarto. 2017. Pengaruh Profitabilitas, Ukuran Perusahaan, dan Kinerja Lingkungan Terhadap Islamic Social Reporting (ISR). Skripsi. Universitas Muhammadiyah Surakarta.

Winarno. 2015. Analisis Ekonometrika dan Statistik Dengan Eviews (ed. Ke-4). Yogyakarta.

Yuvita Sari, Reka. 2018. Pengaruh Ukuran Perusahaan Umur Perusahaan Profitabilitas dan Leverage Terhadap Pengungkapan Islamic Social Reporting Pada Bank Umum Syariah di Indonesia Periode 2013-2017. Skripsi. IAIN Purwokerto. 